УДК [612.015.6+612.115.32]-02:618.173-06:616.36-002.2-085

DOI 10.11603/24116-4944.2019.2.10923

С Л. Є. Лимар, Ю. П. Вдовиченко, І. М. Маланчин, Н. А. Лимар

Тернопільсъкий національний медичний університет ілені І. Я. Горбачевсъкого МОЗ України

Національна медична академія післядипломної освіти імені П. Л. Шупика

КНП «ТОКПЦ «Мати і дитина» ТОР, Тернопіль

\title{
РІВЕНЬ КАЛЬЦІЮ І ВІТАМІНУ D У ЖІНОК ІЗ ПОРУШЕННЯМИ МЕНСТРУАЛЬНОЇ ФУНКЦІЇ НА ТЛІ ХРОНІЧНИХ ГЕПАТИТІВ ТА ЙОГО КОРЕКЦІЯ
}

Мета дослідження - визначення рівня кальцію і вітаміну D у жінок із порушеннями менструальної фрункції (ПМФ) на тлі хронічного гепатиту (ХГ), його впливу на якість життя жінок та комплексна терапія.

Матеріали та методи. Обстежено 77 жінок репродуктивного віку (від 18 до 43 років) із ПМФ на тлі ХГ: аномальними матковими кровотечами (АМК) та дисменореєю. У контрольній групі було 30 жінок із ПМФ без патології печінки. Вивчено прояви ПМФ, визначено рівень кальцію, вітаміну D, білкових фрракцій при загостренні та ремісії ХГ, оцінено якість життя жінок.

Результати дослідження та їх обговорення. Пацієнток було розподілено на 2 групи залежно від методу лікування. Виявлено достовірне зниження рівня кальцію, вітаміну D та альбуміну, отримані результати підтверджують літературні дані. У жінок обох груп до лікування спостерігали помірний рівень зниження якості життя. Застосування в комплексній терапії комбінованого препарату кальцію з вітаміном D сприяло достовірному підвищенню рівня кальцію, вітаміну D та альбуміну. У 2 групі підвищився рівень якості життя за рахунок фрізичного здоров'я. У доступній для обробки літературі ми не знайшли подібних досліджень при зазначеній коморбідній патології.

Висновки. У жінок з ПМФ на тлі загострення ХГ спостерігається зниження рівня кальцію та вітаміну D в крові, що призводить до погіршення якості життя. Комплексна терапія з урахуванням дефіциту кальцію та вітаміну D забезпечує тривалу ремісію та покращує якість життя пацієнток.

Ключові слова: порушення менструальної функції; хронічний гепатит; кальцій; вітамін D; якість життя.

УРОВЕНЬ КАЛЬЦИЯ И ВИТАМИНА D У ЖЕНЩИН С НАРУШЕНИЕМ МЕНСТРУАЛЬНОЙ ФУНКЦИИ НА ФОНЕ ХРОНИЧЕСКОГО ГЕПАТИТА И ЕГО КОРРЕКЦИЯ

Цель исследования - определение уровня кальция и витамина D у женщин с нарушениями менструальной функции (НМФ) на фоне хронического гепатита (ХГ), его влияния на качество жизни и комплексная терапия.

Материалы и методы. Обследовано 77 женщин репродуктивного возраста (от 18 до 43 лет) с НМФ на фоне ХГ: аномальными маточными кровотечениями (АМК) и дисменореей. В контрольной группе было 30 женщин с НМФ без патологии печени. Изучены проявления НМФ, проведено определение уровня кальция, витамина D, белковых фрракций при обострении и ремиссии ХГ, оценено качество жизни.

Результаты исследования и их обсуждение. Пациентки разделены на 2 группы в зависимости от метода лечения. Выявлено достоверное снижение уровня кальция, витамина D и альбумина, полученные результаты подтверждают литературные данные. У женщин обеих групп до лечения наблюдался умеренный уровень снижения качества жизни. Применение в комплексной терапии комбинированного препарата кальция с витамином D способствовало достоверному повышению уровня кальция, витамина D и альбумина. Bo 2 группе повысился уровень качества жизни за счет фризического здоровья. В доступной для обработки литературе мы не нашли подобных исследований при указанной коморбидной патологии.

Выводы. У женщин с НМФ на фроне обострения ХГ наблюдается снижение уровня кальция и витамина D в крови, что приводит к ухудшению качества жизни. Комплексная терапия с учетом десрицита кальция и витамина D обеспечивает длительную ремиссию и улучшает качество жизни пациенток.

Ключевые слова: нарушение менструальной функции; хронический гепатит; кальций; витамин D; качество жизни.

LEVEL OF CALCIUM AND VITAMIN D IN WOMEN WITH DISORDERS OF THE MENSTRUAL FUNCTION ON THE BACKGROUND OF CHRONIC HEPATITIS AND ITS CORRECTION

The aim of the study - to determine the level of calcium and vitamin D in women with MD against the background of $\mathrm{CH}$ their effect on the quality of life of women and complex therapy.

Materials and Methods. 77 women of reproductive age (from 18 to 43 years old) with MD and CH were studied: abnormal uterine bleeding (UB) and dysmenorrhea. In the control group 30 women with MD without pathology of the liver. The manifestations of $\mathrm{MD}$, the determination of the level of calcium, vitamin $\mathrm{D}$, protein fractions in exacerbation and remission of $\mathrm{CH}$, the quality of life of women were assessed.

Results and Discussion. The patients were divided into 2 groups depending on the treatment method. A significant decrease in the level of calcium, vitamin D and albumin was found, and the obtained results confirm the literature data. In both groups, moderate levels of quality of life were observed. Application in the complex therapy of combined calcium with vitamin $D$ is contributed to a significant increase in the level of calcium, vitamin D and albumin. In 2 groups, the level of quality of life increased due to physical health. In literature available for processing, we did not find similar studies for this comorbidity.

Conclusions. In women with $\mathrm{MD}$ and $\mathrm{CH}$ there is a decrease in the level of calcium and vitamin $\mathrm{D}$ in the blood, which leads to a deterioration in the quality of life. Complex calcium and vitamin D deficiency therapy provides long remission and improves patient quality of life.

Key words: violation of menstrual function; chronic hepatitis; calcium; vitamin D; quality of life. 
ВСТУП. Порушення менструальної фрункції (ПМФ) впродовж останніх десятиліть залишається серйозною проблемою, яка турбує науковців і практичних лікарів, оскільки зростає не лише кількість ПМФ, але й наявність коморбідної патології [12], що ускладнює перебіг захворювання та погіршує якість життя (ЯЖ) молодих жінок $[1-10,13]$. Сьогодні значною мірою зростає захворюваність на хронічні гепатити (ХГ) різного ґенезу [4]. Оскільки роль печінки є визначальною не лише в метаболізмі гормонів в організмі жінки, але й впливає на обмінні процеси, нас зацікавило визначення рівня кальцію та вітаміну $D$ у жінок з ПМФ на тлі ХГ та його впливу на ЯЖ пацієнток [7-11]. Медичні аспекти Яж включають вплив захворювання на повсякденну життєдіяльність людини [1-11].

МЕТА ДОСЛІДЖЕННЯ - визначення рівня кальцію та вітаміну D у жінок з ПМФ на тлі ХГ і його впливу на якість життя жінок із коморбідною патологією.

МАТЕРІАЛИ ТА МЕТОДИ. БУЛо обстежено 77 жінок репродуктивного віку (від 18 до 43 років) із ПМФ на тлі ХГ різного ґенезу. ПМФ проявлялись аномальними матковими кровотечами (АМК) різного ступеня інтенсивності та дисменореєю. У контрольній групі спостерігали 30 жінок із ПМФ без патології печінки. Дослідження проводили на кафедрі акушерства та гінекології № 1 ТНМУ імені І. Я. Горбачевського на базі ТОКПЦ «Мати і дитина» впродовж 5 років. Вивчено особливості менструальної функції пацієнток, прояви ПМФ, проведено фрізикальне обстеження, визначення клінічних, біохімічних показників та маркерів гепатитів B, C, рівня гонадотропних гормонів, естрадіолу, прогестерону в 1 та 2 фрази менструального циклу, АлАТ, АсАТ, ГГТ, ЛФ, білірубіну, глюкози, білкових срракцій, кальцію (колориметричним методом), іонізованого кальцію (методом іоноселективного аналізу) при загостренні та ремісії ХГ. Якість життя жінок оцінено шляхом анкетування за допомогою опитувальника SF-36 Health Status Survey, який належить до неспецисрічних опитувальників для оцінки якості життя. Усі 36 пунктів опитувальника розподілено на вісім шкал. Шкали групуються в два показники: «фрізичний компонент здоров'я» та «психологічний компонент здоров'я». Визначали медіану для опису характеристики отриманих даних. Статистичну обробку результатів лабораторних досліджень здійснювали з використанням сучасних методів варіаційної статистики за допомогою стандартних програм статистичного аналізу Microsoft Excel 5.0.

РЕЗУЛЬТАТИ ДОСЛІДЖЕННЯ ТА ЇХ ОБГОВОРЕННЯ. Було обстежено 77 жінок репродуктивного віку (від 18 до 43 років) з ПМФ на тлі ХГ різного ґенезу. 3 них у 47 жінок аномальні маткові кровотечі (АМК) поєднувались із вираженими проявами дисменореї. Вплив порушення срункції печінки висвітлено в попередніх дослідженнях: виявлено, що суттєвий вплив на менструальну функцію мають загострення ХГ, причому важливий не лише ґенез гепатиту, але особливе значення має функціональний стан печінки [4]. Середній вік жінок з АМК склав 31,7 року. Загальний масив жінок був розділений на 2 групи залежно від лікування коморбідної патології. Обидві групи були пропорційні за віком. ХГ спостерігались від 2 до 14 років. У пацієнток обох груп загострення вказаних захворювань були пропорційними. Виявлені ознаки захворювання підтверджують літературні дані [1-3,7-10]. Всі пацієнтки консультовані гепатологом, інфекціоністом і отримували лікування загострення ХГ відповідно до призначень профрільних спеціалістів. Лікування АМК проводили згідно з протоколом МОЗ України. До 1 групи ввійшли 30 жінок з АМК, які страждають від ХГ різного ґенезу; які отримували лікування без врахування рівня кальцію та вітаміну D; до 2 групи - 47 жінок з АMK, які отримували комплексну терапію з використанням комбінованого препарату кальцію, з вітаміном D. Кожна таблетка препарату містить 500 мг кальцію (у вигляді кальцію карбонату та кальцію цитрату), 200 МО вітаміну $\mathrm{D}_{3}, 40$ мг магнію, 7,5 мг цинку, 1 мг міді, 1,8 мг марганцю, 250 мкг бору, приймання по 1 таблетці під час їди 1-2 рази на добу впродовж 2 місяців. Менструальну функцію визначали за такими показниками: менархе, тривалість менструального циклу, тривалість фрази десквамації та кількість менструальної крові, двофазність, суб'єктивні прояви дисменореї. Отримані результати відповідають літературним даним $[1,2,5-7,10]$. Середня тривалість гінекологічного захворювання в досліджуваних групах коливалась від 3 до 12 років. Виявлено пряму кореляційну залежність АМК та загострення ХГ. Тривалість кровотечі до лікування в 1 групі склала $(12,4 \pm 2,7)$ дня; у 2 групі - $(13,7 \pm 2,4)$ дня. Після лікування фраза десквамації в 1 групі тривала $(7,3 \pm 1,8)$ дня; у 2 групі $(6,2 \pm 1,5)$ дня, що достовірно менше, ніж до лікування $(p<0,05)$. Загальна

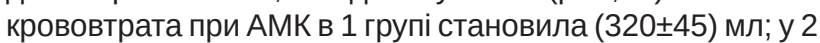

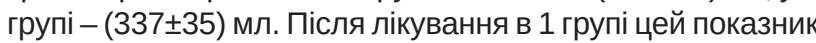

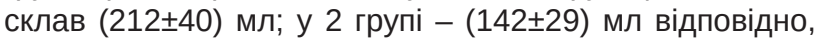
що достовірно нижче, ніж в 1 групі $(p<0,05)$. Показники кальцію, вітаміну D та альбуміну в жінок з AMK при загостренні ХГ представлено в таблиці 1.

Як видно з таблиці, у жінок обох груп до лікування спостерігали зниження рівня кальцію, вітаміну D та альбуміну. Після лікування АМК та загострення ХГ без врахування показників кальцію та вітаміну D відмічали несуттєве покращення досліджуваних показників, яке не було достовірно значущим [8, 9, 11]. При застосуванні в

Таблиця 1. Рівень кальцію, вітаміну D та альбуміну в обстежуваних жінок

\begin{tabular}{||l|c|c|c|c|c||}
\hline \multirow{2}{*}{ Показник } & \multicolumn{2}{|c|}{1 група, $\mathrm{n}=30$} & \multicolumn{2}{c||}{2 група, $\mathrm{n=47}$} & \multirow{2}{*}{ Контроль, $\mathrm{n}=30$} \\
\cline { 1 - 5 } & до лікування & після лікування & до лікування & після лікування & \\
\hline Кальцій (ммоль/л) & $1,5 \pm 0,3$ & $1,9 \pm 0,4$ & $1,4 \pm 0,3$ & $2,3 \pm 0,3^{*}$ & $2,5 \pm 0,3$ \\
\hline Вітамін D (нг/мл) & $4,9 \pm 1,1$ & $7,7 \pm 1,2$ & $4,8 \pm 2,4$ & $11,6 \pm 3,2^{*}$ & $16,7 \pm 4,9$ \\
\hline Альбумін(г/л) & $32,4 \pm 1,7$ & $35,2 \pm 1,4$ & $32,1 \pm 2,3$ & $43,7 \pm 2,1^{*}$ & $46,2 \pm 2,9$ \\
\hline
\end{tabular}

Примітка. ${ }^{*}$ - достовірність порівняння із показниками до лікування $(p<0,05)$. 
комплексній терапії комбінованого препарату кальцію 3 вітаміном D виявлено достовірно вищі показники кальцію, вітаміну D та альбуміну після проведеного курсу лікування. Контрольне обстеження проводили через 6 місяців. У 1 групі у 2 пацієнток (6,7 \%) відновились АМК на тлі загострення ХГ. У 2 групі спостерігали стійку ремісію ХГ, рецидивів АМК не було.

Якість життя жінок оцінено шляхом анкетування за допомогою опитувальника SF-36 Health Status Survey [3] Застосовували спосіб шкали градацій, у якому значення шкал варіюють від 0 до 100 балів. Встановлено таку градацію відмінностей: зміни 5-10 балів - слабкі; зміни 10-20 балів - помірні; зміни понад 20 балів - значно виражені.

Шкали групуються в два показники: «фрізичний компонент здоров'я» та «психологічний компонент здоров'я»:

1. Фізичний компонент здоров'я (Physical health-PH).

Складові шкали:

- фрізичне фрункціонування;

- рольове функціонування, яке зумовлено фрізичним станом;

- інтенсивність болю;

- загальний стан здоров'я.

2. Психологічний компонент здоров'я (Mental HealthМН). Складові шкали:

- психічне здоров'я;

\section{СПИСОК ЛІТЕРАТУРИ}

1. Жук С. И. Алгоритмы оказания помощи при аномальных маточных кровотечениях / С. И. Жук // Жіночий лікар. - 2015. - № 4 (60). - С. 22-30.

2. Аномальные маточные кровотечения у женщин в пременопаузе: клиническое практическое руководство Международной оредерации гинекологов и акушеров (FIGO), Общества акушеров и гинекологов Канады (SOGO) // Репродуктивная эндокринология. - 2013. - № 5 (13). - С. 78-106.

3. Якість життя та прихильність до лікування в клініці внутрішніх хвороб : навч. посіб. / уклад.: В. І. Кривенко, І. С. Качан, С. П. Пахомова, О. П. Федорова, М. Ю. Колесник, І. В. Непрядкіна, Т. Ю. Гріненко. - Запоріжжя, 2015. - 80 с.

4. Лимар Л. Є. Деякі аспекти патогенезу розладів менструальної фрункції при хронічних гепатитах / Л. Є. Лимар, Н. А. Лимар // Актуальні питання педіатрії, акушерства та гінекології. - 2015. - № 1. - С. 145-148.

5. Манухин И. Б. Гинекологическая эндокринология : клинические лекции / И. Б. Манухин, Л. Г. Тумилович, М. А. Геворкян. - 3-е изд, перераб. - М. : ГЭОТАР-Медиа, 2014. - $270 \mathrm{c}$.

6. Мілевська Н. В. Аменорея у дівчат-підлітків: причини, діагностика / Н. В. Мілевська // Жіночий лікар. - 2017. - № 1 (69). - C. 60-63.

7. Наказ МОЗ України «Аномальні маткові кровотечі»

\section{REFERENCES}

1. Zhuk, S.I. (2015). Algoritmy okazaniya pomoshchi pri anomalnykh matochnykh krovotecheniyakh [Algorithms for assisting with abnormal uterine bleeding]. Zhinochyi likar - Woman's Doctor, 4 (60), 22-30 [in Ukrainian].

2. Anomalnyye matochnyye krovotecheniya u zhenshchin v premenopauze: Klinicheskoye prakticheskoye rukovodstvo Mezhdunarodnoy federatsii ginekologov i akusherov (FIGO), Obshchestva akusherov i ginekologov Kanady, 2013 (SOGO)
- рольове фрункціонування, яке зумовлено емоційним станом;

- соціальне функціонування;

- життєва активність [3, 8-11].

У 1 та 2 групі до лікування виявлено помірний рівень зниження якості життя (на 17,3 бала в 1 групі та на 18,4 бала у 2 групі), причому рівномірно за рахунок фрізичного та психічного здоров'я. Після лікування в 1 групі цей показник залишився на середньому рівні і склав 12,1 бала за рахунок фрізичного здоров'я. У 2 групі - 5,6 бала за рахунок психічного здоров'я.

У доступній для обробки літературі ми не знайшли подібних досліджень при вказаній коморбідній патології.

ВИСНОВКИ. 1. У жінок з ПМФ на тлі загострення ХГ спостерігається зниження рівня кальцію та вітаміну D в крові, що призводить до погіршення якості життя.

2. Комплексна терапія з урахуванням дефіциту кальцію та вітаміну D забезпечує тривалу ремісію та покращує якість життя пацієнток.

ПЕРСПЕКТИВИ ПОДАЛЬШИХ ДОСЛІДЖЕНЬ. ПЛАнуємо продовжувати дослідження окремих ланок патогенезу ПМФ для розробки та вдосконалення комплексної терапії вказаної патології. Проводитимемо дослідження впливу десріциту кальцію на перебіг вагітності у жінок із хронічними гепатитами та ПМФ в анамнезі.

№ 353 від 13.04.2016. - К., 2016. - 15 с

8. Семенина Г. Б. Ендокринні та обмінно-метаболічні порушення в жінок із синдромом полікістозних яєчників і нові можливості їхньої корекції / Г. Б. Семенина // Репродуктивна ендокринологія. - 2016. - № 6. - С. 15-17.

9. Поворознюк В. В. Десріцит вітаміну D у населення України та чинники його розвитку / В. В. Поворознюк, Н. І. Балацька // Репродуктивна ендокринологія. - 2013. - № 5 (13). - C. 7-13.

10. Татарчук Т. Ф. Современный менеджмент аномальных маточных кровотечений / Т. Ф. Татарчук, О. А. Ефименко // Репродуктивная эндокринология. - 2013. - № 4 (12). - С. 1-11.

11. Grundmann V. Vitamin D - roles in women's reproductive health? / V. Grundmann, F. von Versen-Huynck // Reproductive Biology and Endocrinology. - 2011. - Vol. 2 (9). - P. 5116.

12. Вивчення впливу віку та індексу коморбідності на ризик тромботичних ускладнень у хворих на рак ендометрія на доопераційному етапі / Б. Д. Кривокульський, І.В.Жулкевич, Д. Б. Кривокульський, Л. В. Шкробот // Вісник наукових досліджень. - 2018. - № 2. - С. 150-154.

13. Роль санітарно-просвітницької діяльності лікарських громадських організацій в профрілактиці захворювань / О. Бакалюк, І. Жулкевич, О. Ревякіна, М. Куцин // Український медичний часопис. - 1998. - № 2 (1-2). - С. 132-133.

[Abnormal Uterine Bleeding In Pre-Menopausal Women : Clinical practice guideline of the International Federation of Gynecology and Obstetrics (FIGO), Society of Obstetricians and Gynaecologists of Canada, 2013 (SOGO)]. (2013). Reproduktivnaya endokrinologiya - Reproductive Endocrinology, 5 (13), 78-106 [in Ukrainian].

3. Kryvenko, V.I., Kachan, I.S., Pakhomova, S.P., Fedorova, O.P., Kolesnyk, M.Yu., Nepryadkina, I.V., \& Hrinenko, T.Yu. 
(contribution) (2015). Yakist zhyttia ta prykhylnist do likuvannia v klinitsi vnutrishnikh khvorob: navch. posib [Quality of life and adherence to treatment in an internal medicine clinic: Tutorial]. Zaporizhzhia [in Ukrainian].

4. Lymar, L.Ye., \& Lymar, N.A. (2015). Deiaki aspekty patohenezu rozladiv menstrualnoi funktsii pry khronichnykh hepatytakh [Some aspects of pathogenesis menstrual function in chronic hepatitis]. Aktualni pytannia pediatrii, akusherstva ta hinekolohii - Actual Problems of Pediatry, Obstetrics and Gynecology, 1, 145-148 [in Ukrainian].

5. Manukhin, I.B., Tumilovich, L.G., \& Gevorkyan, M.A. (2014). Ginekologicheskaya endokrinologiya: klinicheskiye lektsii [Gynecological endocrinology: clinical lectures]. Moscow: GEOTAR-Media [in Russian].

6. Milevska, N.V. (2017). Amenoreia u divchat-pidlitkiv: prychyny, diahnostyka [Amenorrhea in adolescent girls: causes, diagnosis]. Zhinochyi likar - Woman's Doctor, 1 (69), 60-63 [in Ukrainian].

7. (2016). Nakaz MOZ Ukrainy "Anomalni matkovi krovotechi" № 353 vid 13.04.2016 [Order of the Ministry of Health of Ukraine "Abnormal uterine bleeding" No. 353 from 13.04.2016]. Kyiv [in Ukrainian].

8. Semenyna, H.B. (2016). Endokrynni ta obminno-metabolichni porushennia $v$ zhinok iz syndromom polikistoznykh yaiechnykiv i novi mozhlyvosti yikhnoi korektsii [Endocrine and metabolic disorders in women with polycystic ovary syndrome and new opportunities for their correction]. Reproduktyvna endokrynolohiia - Reproductive Endocrinology, 6, 15-17 [in Ukrainian].
9. Povorozniuk, V.V., \& Balatska, N.I. (2013). Defitsyt vitaminu D u naselennia Ukrainy ta chynnyky yoho rozvytku [Vitamin $D$ deficiency in the population of Ukraine and factors for its development]. Reproduktyvna endokrynolohiia - Reproductive Endocrinology, 5 (13), 7-13 [in Ukrainian].

10. Tatarchuk, T.F., \& Yefimenko, O.A. (2013). Sovremennyy menedzhment anomalnykh matochnykh krovotecheniy [Modern management of abnormal uterine bleeding]. Reproduktyvna endokrynolohiia - Reproductive Endocrinology, 4 (12), 1-11 [in Russian].

11. Grundmann, V., \& von Versen-Huynck, F. (2011). Vitamin $\mathrm{D}$ - roles in women's reproductive health? Reproductive Biology and Endocrinology, 2 (9), 5116.

12. Kryvokulskyi, B.D., Zhulkevych, I.V., Kryvokulskyi, D.B., \& Shkrobot, L.V. (2018). Vyvchennia vplyvu viku ta indeksu komorbidnosti na ryzyk trombotychnykh uskladnen u khvorykh na rak endometriia na dooperatsiinomu etapi [Studying the influence of age and comorbidity index on the thrombotic complications risk in patients with endometrial cancer at preoperative stage]. Visnyk naukovykh doslidzhen - Bulletin of Scientific Research, 2, 150-154 [in Ukrainian].

13. Bakaliuk, O., Zhulkevych, I., Reviakina, O., \& Kutsyn, M. (1998). Rol sanitarno-prosvitnytskoi diialnosti likarskykh hromadskykh orhanizatsii v profilaktytsi zakhvoriuvan [The role of sanitary and educational activity of medical public organizations in disease prevention]. Ukrainskyi medychnyi chasopys - Ukrainian Medical Journal, 2 (1-2), 132-133 [in Ukrainian]. 